\title{
ANALISIS PENGARUH FAKTOR FUNDAMENTAL PERUSAHAAN DAN \\ RISIKO SISTEMATIS TERHADAP RETURN SAHAM
}

\author{
Dyatri Utami Arian Absari \\ Pascasarjana Fakultas Ekonomi dan Bisnis Universitas Brawijaya Malang \\ Jl. Mayjen Haryono 165 Malang \\ No Telephon: 082143687361;email:dyatriutami@gmailcom
}

Made Sudarma

Pascasarjana Fakultas Ekonomi dan Bisnis Universitas Brawijaya Malang Jl. Mayjen Haryono 165 Malang. No Telephon: 0811361349

\section{Grahita Chandrarin}

Pascasarjana Fakultas Ekonomi dan Bisnis Universitas Brawijaya Malang Jl. Mayjen Haryono 165 Malang. No Telephon: 08123301464

\begin{abstract}
This research aim to know influance of fundamental factors as financial ratio with proxy liquidity, asset size, debt equity ratio (DER), return on equity (ROE), earnings per share (EPS), price earnings ratio (PER) and systematic risk to the rate of return in Indonesian Stock Exchange. Manufacturing company as sample the taken amount to 54 emiten the listed in Indonesia Stock Exchange with period of research between of 2008 up to year of 2011. Analysis method the used is multiple linear regression. Analysis results indicate that from some element fundamental factor be like liquidity, asset size, debt equity ratio (DER), return on equity (ROE), earnings per share (EPS), price earnings ratio (PER) and systematic risk simultanly there are the influence significant to the profitability represented by rate of return. Partially show only earnings per share (EPS) and systematic risk with explained by variation the expressed in adjusted $\mathrm{R}^{2}$ equal to $7,8 \%$ is while the rest equal to 92,2 $\%$ influenced by other variable which is not explained by this research model. Where as other variable not influence with models is liquidity, asset size, debt equity ratio (DER), return on equity (ROE) and price earnings ratio (PER). Research result pursuant to hypothesis test indicate that between some element fundamental factors is most dominant influence the rate of return at the manufacturing company of listed in Indonesia Stock Exchange is systematic risk.
\end{abstract}

Keywords : Rate Of Return, Liquidity, Asset size, Debt Equity Ratio (DER), Return On Equity (ROE), Earnings Per Share (EPS), Price Earnings Ratio (PER) and Systematic Risk.

\section{PENDAHULUAN}


Pasar modal mempunyai peranan sangat penting dalam perekonomian suatu negara, hal ini dikarenakan pasar modal menjalankan fungsi ekonomi sekaligus fungsi keuangan. Di lihat dari sudut pandang ekonomi, pasar modal berfungsi sebagai salah satu sistem mobilitas dana jangka panjang yang efisien bagi pemerintah. Melalui pasar modal pemerintah dapat mengalokasikan dana masyarakat ke sektor investasi yang produktif. Di lihat dari sudut pandang keuangan, pasar modal berfungsi sebagai salah satu media yang efisien untuk mengalokasikan dana dari pihak-pihak yang mempunyai kelebihan dana yaitu investor dan pihak yang membutuhkan dana yaitu perusahaan.

Perkembangan pasar modal di Indonesia yang pesat merupakan indikator bahwa pasar modal merupakan alternatif sumber dana disamping perbankan, selain itu dengan semakin berkembangnya pasar modal juga menunjukkan bahwa kepercayaan pemodal akan investasi di pasar modal Indonesia cukup baik. Investasi merupakan penundaan konsumsi pada saat ini dengan tujuan mendapatkan tingkat pengembalian (return) yang akan diterima di masa yang akan datang. Investasi pada saham dianggap mempunyai tingkat risiko yang lebih besar dibandingkan dengan alternatif investasi lain, seperti obligasi, deposito, dan tabungan. Investor maupun calon investor dapat memperkirakan berapa tingkat pengembalian yang diharapkan (expected return) dan seberapa jauh kemungkinan hasil yang sebenarnya nanti akan menyimpang dari hasil yang diharapkan. Apabila kesempatan investasi mempunyai tingkat risiko yang lebih tinggi, maka investor akan mengisyaratkan tingkat keuntungan yang lebih tinggi pula. Dengan kata lain, semakin tinggi risiko suatu kesempatan investasi maka akan semakin tinggi pula tingkat keuntungan (return) yang diisyaratkan oleh investor (Hartono, 2003: 130).

Investasi di pasar modal mengakibatkan meningkatnya jumlah investor yang beralih dari sektor perbankan ke dalam sektor pasar modal. Investor dalam menanamkan dananya membutuhkan berbagai informasi yang berguna untuk memprediksi hasil investasinya dalam pasar modal. Untuk melakukan analisis tentang return saham tersebut diperlukan adanya informasi yang bersifat fundamental dan teknikal. Analisis fundamental didasarkan pada informasiinformasi yang diterbitkan oleh emiten maupun administrator bursa efek. Analisis ini dimulai dari siklus perusahaan secara umum, selanjutnya kesektor industrinya, 
akhirnya dilakukan evaluasi terhadap harga saham yang diterbitkan. Sedangkan analisis teknikal didasarkan pada data (perubahan) harga saham di masa lalu sebagai upaya untuk memperkirakan harga saham di masa mendatang. (Halim, 2005: 29).

Informasi fundamental merupakan informasi yang berhubungan dengan kondisi perusahaan yang umumnya ditunjukkan dalam laporan keuangan yang merupakan salah satu ukuran kinerja perusahaan. Informasi fundamental sering digunakan untuk memprediksi harga saham. Laporan keuangan dapat diketahui beberapa informasi fundamental antara lain: rasio-rasio keuangan, arus kas, serta ukuran-ukuran kinerja lainnya yang dihubungkan dengan return saham. Dalam melakukan investasi saham investor berharap memperoleh keuntungan baik deviden atau capital gain karena terjadinya apresiasi harga saham. Apresiasi harga saham terjadi karena penilaian pasar yang dilakukan baik dengan menggunakan faktor fundamental mikro ataupun makro dan faktor teknikal lainnya.

Warsono (2008) menyatakan bahwa kinerja suatu pasar modal ditentukan oleh berbagai macam faktor. Faktor-faktor inilah yang pada umumnya berpengaruh terhadap kinerja pasar modal secara simultan, salah satunya adalah kondisi fundamental perusahaan-perusahaan yang beroperasi. Faktor fundamental perusahaan merupakan faktor kinerja yang dihasilkan oleh perusahaan atas operasioperasi yang dilakukannya. Indikator yang di gunakan pada umumnya berbasis kinerja keuangan. Suatu perusahaan atau industri dengan kinerja keuangan yang baik, maka akan di respon oleh pasar dengan baik pula. Bentuk respon pasar ini berupa kenaikan harga sekuritas-sekuritas yang di perdagangkan di pasar modal. Jika seluruh perusahaan yang sekuritas-sekuritasnya di perdagangkan di pasar modal mempunyai fundamental yang baik, maka kondisi pasar modalnya juga akan membaik dan sebaliknya.

Robert Ang (1997) menyatakan bahwa analisis fundamental pada dasarnya adalah melakukan analisis historis atas kekuatan keuangan dari suatu perusahaan, dimana proses ini sering juga disebut sebagai analisis perusahaan (company analysis). Data historis mencerminkan keadaan keuangan yang telah lalu yang digunakan sebagai dasar untuk memproyeksikan keadaan keuangan perusahaan dimasa depan. Dalam company analysis para investor (pemodal) akan mempelajari 
laporan keuangan perusahaan dengan tujuan untuk menganalisis kinerja perusahaan dengan mengetahui kekuatan dan kelemahan perusahaan, mengidentifikasi kecenderungan dan mengevaluasi efisiensi operasional serta memahami sifat dasar dan karakter operasional perusahaan.

Berinvestasi di pasar modal selain faktor keuntungan, investor juga harus mempertimbangkan faktor risiko. Saham perusahaan yang go publik sebagi komoditi investasi tergolong berisiko tinggi, karena sangat peka terhadap perubahan yang terjadi baik di dalam, maupun di luar negeri, perubahan di bidang politik, ekonomi, moneter, peraturan perundang-undang, perubahan dalam industri dan perubahan dari perusahaan itu sendiri.

Risiko investasi di pasar modal pada dasarnya terdiri atas dua risiko yaitu risiko sistematik (systematic risk) dan risiko tidak sistematik (unsystematic risk). Husnan (1994) menyatakan bahwa risiko sistematik cenderung mempunyai dua sifat. Pertama relatif sama pengaruhnya terhadap semua saham perusahaan yang ada di pasar sehingga risiko sistematik ini disebut juga sebagai risiko pasar (market risk). Kedua tidak dapat dihilangkan melalui diversifikasi investasi dalam portofolio investasi. Risiko yang relevan untuk dipertimbangkan oleh investor dalam pengambilan keputusan investasi adalah risiko sistematik atau risiko pasar (Husnan,1994), sebab investor dapat mengeliminasi risiko tidak sistematik melalui pembentukan portofolio investasi. Dalam literatur keuangan, risiko sistematik atau risiko pasar sering dinyatakan dengan beta $(\beta)$. Dengan demikian untuk kepentingan investasi, investor harus menaksir besarnya beta saham sebagai ukuran risiko investasi di pasar modal.

Penelitian ini menggunakan industri pengolahan dan manufaktur. Perusahaan manufaktur dipilih karena secara umum perusahaan ini memiliki risiko bisnis yang lebih tinggi daripada jenis industri yang lain (Husnan, 1999: 33). Faktor yang menjadikan perusahaan manufaktur menarik untuk dijadikan obyek dalam penelitian ini adalah industri dalam kelompok ini mengalami pergerakan return saham yang sangat fluktuatif selama periode 2008 sampai dengan tahun 2011. Tabel 1.1 berikut ini adalah data perkembangan return saham dari kelompok perusahaan manufaktur yang listed di Bursa Efek Indonesia dalam kurun waktu tahun 2008 sampai dengan tahun 2011. 
Tabel 1.1

Pergerakan Ratio Return Saham Perusahaan Manufaktur Yang Listed di Bursa Efek Indonesia Periode 2008 - 2011.

\begin{tabular}{|c|c|c|c|}
\hline \multicolumn{1}{|l|}{ Tahun } & Minimum & Maksimum & \multicolumn{1}{|l|}{ Mean } \\
\hline 2008 & $-1,21$ & 1,74 &,- 0843 \\
\hline 2009 &,- 69 & 2,44 &, 6727 \\
\hline 2010 &,- 29 & 3,45 &, 6600 \\
\hline 2011 & $-1,74$ & 1,67 &, 1408 \\
\hline
\end{tabular}

Sumber : Data sekunder yang diolah

Tabel 1.1 di atas memperlihatkan kondisi yang sangat menarik. Sepanjang periode analisis, selalu ada perusahaan yang menghasilkan return saham yang negatif. Return saham minimum dari tahun 2008 sampai tahun 2011 secara berturut-turut sebesar $-1,21 ;-0,69 ;-0,29 ;-1,74$, yaitu return saham dari KAEF (Kimia Farma, Tbk), ARNA (Arwana Citra Mulia, Tbk), TURI (Tunas Ridean, Tbk), INTP (Indocement Tunggal Prakarsa, Tbk). Return saham maksimum dari tahun 2008 sampai tahun 2011 secara berturut-turut sebesar 1,74;2,44; 3,45; 1,67 yaitu return saham dari BTON (Betonjaya Manunggal, Tbk), LMPI (Langgeng Makmur Industry, Tbk), INDS (Indospring, Tbk), IGAR (Kageo Igar Jaya, Tbk).

Rata-rata return saham terendah terdapat pada tahun 2008, yaitu sebesar 0,0843. Nilai return saham bertanda negatif ini menunjukkan bahwa secara umum harga saham perusahaan sampel mengalami penurunan. Standar deviasi return saham pada tahun 2008 sebesar 61407 yang melebihi nilai rata-rata return saham sebesar -,0843 atau -8,43\%. Dengan besarnya simpangan data menunjukkan tingginya fluktuasi data variabel return saham selama periode pengamatan.

Rata-rata return saham tertinggi terdapat pada tahun 2009, yaitu sebesar 0,6727. Nilai suatu perusahaan bisa dilihat dari return saham perusahaan yang bersangkutan di pasar modal. Return saham biasanya berfluktuasi mengikuti kekuatan permintaan dan penawaran. Fluktuasi return saham mencerminkan seberapa besar minat investor terhadap saham suatu perusahaan. Return saham setiap saat bisa mengalami perubahan seiring dengan minat investor untuk menempatkan modalnya pada suatu saham. Untuk lebih jelasnya dapat dilihat pada grafik berikut.

Gambar 1.1 
Pergerakan Return Saham Perusahaan Manufaktur Periode 2008 - 2011

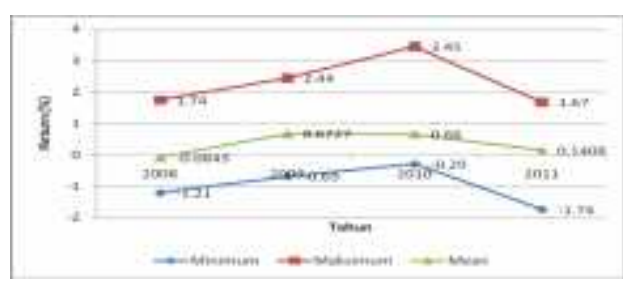

Sumber : Data sekunder yang diolah

Gambar 1.1 di atas menunjukkan selama periode analisis yaitu dari tahun 2008 sampai dengan tahun 2011 terjadi pergerakan dengan arah yang menarik untuk dianalisis. Baik dari terendah, rata rata maupun tertinggi terdapat kecenderungan menaik dari tahun 2008 sampai dengan tahun 2010 kemudian dari tahun 2010 ke tahun 2011 semuanya menunjukan arah yang menurun. Pada tahun 2009 dan tahun 2010 nampaknya menjadi titik balik bagi industri manufaktur kearah kondisi yang lebih baik . Dari grafik tersebut juga nampak bahwa sepanjang periode analisis tetap saja ada return terendah yang bernilai negatif.

Beberapa penelitian tentang return saham sudah banyak dilakukan terkait dengan factor- faktor fundamental mengindikasikan hasil yang tidak konsisten. Penelitian yang menguji rasio-rasio keuangan yang lebih komprehensif telah dilakukan oleh Ou dan Penman (1989). Penelitian Ou dan Penman bertujuan untuk menaksir nilai perusahaan dengan menggunakan Iaporan keuangan. Ou dan Penman menguji manfaat rasio keuangan dalam memprediksi keuntungan saham dan menyeleksi 68 rasio keuangan untuk periode 1965 sampai dengan 1972 dan 18 rasio keuangan untuk periode 1873 sampai dengan 1977 yang signifikan digunakan dalam memprediksi keuntungan saham. Ou dan Penman menggunakan logit regression model dan menemukan bukti bahwa informasi akuntansi (rasio keuangan) mengandung informasi fundamental yang tidak tercermin dalam harga saham.

Lev dan Thiagarajan (1993) memperkenalkan beberapa variabel fundamental yang merefleksikan hubungan antara data akuntansi saat ini yang dapat digunakan untuk memprediksi perubahan laba di masa yang akan datang. Pengujian ini didasarkan pada hubungan antara variabel fundamental dengan return saham. Hasil pengujian ini menyimpulkan bahwa variabel fundamental berhubungan secara signifikan dengan return saham. 
Dhatt et al. (1997) meneliti hubungan antara stock return dengan berbagai variabel fundamental di Pasar Modal Korea dengan periode penelitian dari tahun 1982 sampai dengan tahun 1993. Variabel independen yang digunakan adalah debt equity ratio, earning price ratio, beta, book market ratio, sales price ratio dan firm size. Hasil penelitian menyimpulkan bahwa stock return berkaitan positif dengan DER, B/M dan S/P serta negatif terhadap firm size dan tidak signifikan hubungannya dengan E/P ataupun beta. Hasil ini berbeda dengan hasil penelitian yang dilakukan oleh Anastasia et al. (2003) yang menyatakan bahwa risiko sistematik (beta) mempunyai pengaruh yang signifikan terhadap harga saham perusahaan properti.

Hasil penelitian yang dilakukan oleh Meythi (2006) yang memperoleh hasil bahwa current ratio (CR) yang paling baik dalam memprediksi return saham perusahaan manufaktur sektor basic dan chemical untuk periode 2000-2004. Hasil serupa juga di peroleh dari hasil penelitian Wiksuana (2008) yang membuktikan bahwa current ratio berpengaruh signifikan terhadap return saham. Hasil ini berbeda dengan hasil penelitian yang dilakukan oleh Wira (2008) yang membuktikan bahwa current ratio tidak mempunyai pengaruh yang signifikan terhadap return saham.

Ukuran perusahaan (size) menggambarkan besar kecilnya suatu perusahaan yang ditunjukkan oleh total aktiva, jumlah penjualan, rata-rata tingkat penjualan dan rata-rata total aktiva. Dhatt et al. (1997) membuktikan bahwa ukuran perusahaan tidak berpengaruh terhadap return saham perusahaan manufaktur.

Penelitian yang dilakukan oleh Dhatt et al. (1997), Anastasia et al. (2003), Wiksuana (2008) membuktikan bahwa DER mempunyai pengaruh yang signifikan terhadap terhadap return saham. Hasil serupa juga di peroleh dari hasil penelitian Susilowati (2011) dan Sparta (2011). Sebaliknya, Subalno (2009) menyatakan bahwa DER tidak terbukti berpengaruh terhadap return saham.

Beberapa bukti empiris menunjukkan bahwa ROE yang semakin meningkat belum tentu meningkatkan return dari saham perusahaan tersebut. Anastasia et al. (2003) dan Wiksuana (2008) membuktikan bahwa ROE mempunyai pengaruh yang signifikan terhadap harga saham perusahaan properti. Sebaliknya, Susilowati 
(2011) menyatakan bahwa ROE tidak berpengaruh terhadap return saham perusahaan manufaktur yang terdaftar di BEI tahun 2006 sampai tahun 2008.

Hasil penelitian Sparta (2011) membuktikan bahwa EPS mempengaruhi harga saham perusahaan industri manufaktur. Sebaliknya, Dhatt et al. (1997), Haruman (2005) dan Susilowati (2011) menyatakan bahwa EPS tidak berpengaruh terhadap return saham perusahaan manufaktur.

PER menunjukkan seberapa besar investor berminat untuk membayar tiap satuan moneter untuk pendapatan yang di terimanya. Perusahaan yang diharapkan tumbuh dengan tingkat pertumbuhan yang tinggi (berarti mempunyai prospek yang lebih baik), akan mempunyai PER yang tinggi. Sebaliknya, perusahaan yang di harapkan mempunyai pertumbuhan yang rendah akan mempunyai PER yang rendah juga (Hanafi, 2005: 43). Haruman (2005) membuktikan bahwa PER tidak berpengaruh terhadap tingkat pengembalian saham.

Berdasarkan beberapa hasil penelitian sebelumnya dan masih terbatasnya penelitian mengenai pengaruh faktor fundamental perusahaan terhadap return saham di BEI menjadi motivasi untuk melakukan penelitian ini. Penelitian ini juga dilakukan untuk menguji konsistensi hasil dari penelitian sebelumnya yang dilakukan oleh Anastasia et.al (2003). Dengan harapan bahwa hasil dari penelitian ini dapat menjadi pertimbangan dalam pembuatan keputusan.

Berdasarkan latar belakang masalah yang telah diuraikan di atas, maka dapat disusun rumusan masalah yang mendasari penelitian ini adalah:

Apakah faktor fundamental perusahaan yang terdiri dari: 1) dari Likuiditas, Ukuran Perusahaan (Assets Size), Debt Equity Ratio, Return On Equity, Earnings Per Share, Price Earnings Ratio dan Risiko Sistematis berpengaruh signifikan terhadap Return Saham?

\section{KAJIAN PUSTAKA}

\section{Signalling Theory}

Signalling theory digagas pertama kali oleh Ackerlof et al. yang menjadikan mereka memperoleh Nobel Ekonomi pada tahun 2001. Teori signaling dikembangkan dalam ilmu ekonomi dan keuangan untuk memperhitungkan kenyataan bahwa orang dalam (insiders) perusahaan pada umumnya memiliki 
informasi yang lebih baik dan lebih cepat berkaitan dengan kondisi mutakhir dan prospek perusahaan dibandingkan dengan investor luar. Teori ini menjelaskan bahwa laporan keuangan yang baik merupakan sinyal atau tanda bahwa perusahaan juga telah beroperasi dengan baik. Menurut Sunardi (2010) informasi yang dipublikasikan sebagai suatu pengumuman akan memberikan signal bagi investor dalam pengambilan keputusan investasi. Jika pengumuman tersebut mengandung nilai positif, maka pasar akan bereaksi baik dengan pihak lain. Reaksi pasar ditunjukkan dengan adanya perubahan volume perdagangan saham. Pada waktu informasi diumumkan dan semua pelaku pasar sudah menerima informasi tersebut, pelaku pasar terlebih dahulu menginterpretasikan dan menganalisis informasi tersebut sebagai signal baik bagi investor, maka terjadi perubahan dalam volume perdagangan saham.

Teori Sinyal juga mengemukakan tentang bagaimana seharusnya sebuah perusahaan memberikan sinyal kepada pengguna laporan keuangan. Sinyal tersebut berupa informasi mengenai kondisi perusahaan kepada pemilik ataupun pihak yang berkepentingan. Sinyal yang diberikan dapat juga dilakukan melalui pengungkapan informasi akuntansi seperti laporan keuangan atau dapat berupa promosi serta informasi lain yang menyatakan bahwa perusahaan tersebut lebih baik dari pada perusahaan lain.

\section{Teori Portofolio}

Markowitz mengembangkan suatu teori pada dekade 1950 yang disebut dengan teori portofolio Markowitz. Markowitz menunjukkan bahwa secara umum risiko mungkin dapat dikurangi dengan menggabungkan beberapa sekuritas tunggal ke dalam bentuk portofolio. Teori Markowitz menggunakan beberapa pengukuran statistik dasar untuk mengembangkan suatu rencana portofolio, diantaranya expected return, standar deviasi baik sekuritas maupun portofolio dan korelasi antar return. Teori ini memformulasikan keberadaan unsur return dan risiko dalam suatu investasi, dimana unsur risiko dapat diminimalisir melalui diversifikasi dan mengkombinasikan berbagai instrumen investasi kedalam portofolio.

Teori portofolio Markowitz didasarkan atas pendekatan mean (rata-rata) dan variance (varian), dimana mean merupakan pengukuran tingkat return dan varian merupakan pengukuran tingkat risiko. Teori portofolio Markowitz ini disebut juga 
sebagai mean-Varian Model, yang menekankan pada usaha memaksimalkan ekspektasi return (mean) dan meminimumkan ketidakpastian atau risiko untuk memilih dan menyusun portofolio optimal.

Teori portofolio merupakan teori yang berhubungan mengenai pengembalian portofolio yang diharapkan dan tingkat risiko portofolio yang dapat diterima serta menunjukkan cara pembentukan portofolio yang optimal. Teori portofolio ini saling berkaitan dengan teori pasar modal yang berdasar pada pengaruh keputusan investor terhadap harga sekuritas serta menunjukkan hubungan yang seharusnya terjadi antara pengembalian dan risiko sekuritas jika investor membentuk portofolio yang sesuai dengan teori portofolio.

Pada perkembangan berikutnya pada tahun 1963 William F. Sharpe mengembangkan Single Index Model (Model Indeks Tunggal) yang merupakan penyederhanaan Indeks model yang sebelumnya telah dikembangkan oleh Markowitz. Model Indeks Tunggal menjelaskan hubungan antara return dari setiap sekuritas individual dengan return indeks pasar. Model ini memberikan metode alternatif untuk menghitung varian dari suatu portofolio, yang lebih sederhana dan lebih mudah dihitung jika dibandingkan dengan metode perhitungan markowitz. Pendekatan alternatif ini dapat digunakan untuk dasar menyelesaikan permasalahan dalam penyusunan portofolio. Sebagaimana telah dirumuskan oleh markowitz, yaitu menentukan efficient set dari suatu portofolio, maka dalam Model indeks tunggal ini membutuhkan perhitungan yang lebih sedikit.

\section{Return Saham}

Return Saham adalah tingkat keuntungan yang dinikmati oleh pemodal atas suatu investasi yang dilakukannya. Return yang diterima oleh seorang pemodal yang melakukan investasi tergantung dari instrumen investasi yang di beli. Return atau hasil investasi merupakan tujuan utama bagi investor. Return realisasi merupakan return yang terjadi yang dihitung berdasarkan data historis dan berfungsi sebagai salah satu pengukur kinerja perusahaan. Return historis juga berguna sebagai dasar penentuan return ekspetasi (expected return) di masa datang. Return ekspetasi merupakan return yang diharapkan akan diperoleh investor di masa mendatang (Hartono, 2003: 109). 
Komponen return terdiri dari dua macam yaitu capital gain (keuntungan selisih harga) dan current income (perdagangan lancar). Capital gain merupakan keuntungan yang diterima karena adanya selisih antara harga penjualan dengan harga pembelian saham dari suatu instrumen investasi. Dengan adanya perdagangan maka akan timbul perubahan nilai suatu instrumen investasi yang menghasilkan capital gain. Untuk menentukan besarnya capital gain dilakukan dengan analisis return historis yang terjadi pada periode sebelumnya sehingga dapat ditentukan besarnya tingkat kembalian yang diinginkan. Komponen kedua dari return adalah current income yaitu keuntungan yang diperoleh melalui pembayaran yang bersifat periodik misalkan pembayaran bunga deposito, dividen, bunga obligasi dan sebagainya disebut sebagai pendapatan lancar, maksudnya adalah keuntungan yang diterima biasanya dalam bentuk kas atau setara kas, seperti bunga atau jasa giro dan dividen tunai serta yang setara kas seperti saham bonus atau dividen saham yaitu dividen dibayarkan dalam bentuk saham-saham dan dapat dikonversi menjadi uang kas.

Penelitian ini menggunakan konsep capital gain yaitu selisih antara harga saham saat ini (Closing price pada periode t) dengan harga saham periode sebelumnya (Closing price pada periode t-1) dibagi dengan harga saham periode sebelumnya (Closing price pada periode t-1). Closing price adalah harga penutup atau harga perdagangan terakhir untuk suatu periode. Closing price adalah harga yang paling sering digunakan untuk analisis (Subalno, 2009). Secara matematis return total suatu investasi adalah:

Return total $=$ yield + capital gain $($ loss $)$

Dengan demikian, return total dapat di nyatakan sebagai berikut :

$$
R_{i t}=\frac{\left(P_{i t}-P_{i(t-1)}\right)}{\mathrm{P}_{\mathrm{it}(\mathrm{t}-1)}}
$$

Keterangan:

$\mathrm{R}_{\mathrm{it}} \quad=$ Return saham i pada periode ke- $\mathrm{t}$

$\mathrm{P}_{\mathrm{it}} \quad=$ Harga penutupan saham i pada periode ke- $\mathrm{t}$

$\mathrm{P}_{\mathrm{i}(\mathrm{t}-1)} \quad=$ Harga penutupan saham $\mathrm{i}$ pada periode $\mathrm{t}-1$

Risiko Saham 
Risiko adalah kemungkinan yang dapat diukur dari diperoleh tidaknya suatu nilai. Investasi saham merupakan investasi yang berisiko. Risiko tersebut timbul dari ketidakpastian ekonomi yang menyebabkan tingkat pengembalian aktual yang diperoleh tidak sesuai dengan apa yang diharapkan. Adanya ketidakpastian (uncertainly) ini berarti investor akan memperoleh return di masa mendatang yang belum diketahui persis nilainya, yang bisa dilakukan oleh seorang investor hanyalah memperkirakan berapa keuntungan yang diharapkan dari investasinya dan seberapa jauh kemungkinan hasil yang sebenarnya nanti akan menyimpang dari hasil yang diharapkan (Hartono, 2003: 132).

Dalam konteks portofolio risiko dibedakan menjadi dua, Hartono (2003: 171), yaitu:

Risiko tidak sistematik (unsystematic risk), merupakan risiko yang dapat dihilangkan dengan melakukan diversifikasi, karena risiko ini ada dalam satu perusahaan atau industri tertentu. Fluktuasi risiko ini besarnya berbeda-beda antara satu saham dengan saham yang lain, karena perbedaan tersebut maka masingmasing saham memiliki tingkat sensivitas yang berbeda terhadap setiap perubahan pasar. Misalnya faktor struktur modal, struktur aset, tingkat likuiditas dan tingkat keuntungan. Risiko non-sistematis disebut juga risiko dapat didiversifikasi, risiko unik, risiko residual atau risiko khusus perusahaan. Risiko ini merupakan risiko yang unik bagi perusahaan seperti pemogokan kerja, tuntutan hukum atau bencana alam.

Risiko sistematik (systematic risk), merupakan risiko yang tidak dapat dihilangkan dengan melakukan diversifikasi, karena fluktuasi risiko ini dipengaruhi oleh faktor-faktor makro yang dapat mempengaruhi pasar secara keseluruhan. Misalnya perubahan tingkat bunga, kurs valuta asing dan kebijakan pemerintah.

Sparta (2000) mendefinisikan risiko sistematis sebagai bagian dari perubahan aktiva yang dapat dihubungkan kepada faktor umum yang juga disebut sebagai risiko pasar atau risiko yang tidak dapat dibagi. Besarnya risiko sistematis dapat diukur dengan indeks risiko sistematis yang sering disebut beta saham.

\section{HIPOTESIS PENELITIAN}


Likuiditas yang diukur dengan Curent ratio merupakan indikator jangka pendek terhadap kemampuan perusahaan untuk membayar kewajiban-kewajiban jangka pendeknya dengan menggunakan aktiva lancar yang tersedia (Syamsyudin, 2007: 41). Dengan kata lain, seberapa besar aktiva lancar yang tersedia mampu menutup dengan segera kewajiban lancarnya. Curent ratio yang semakin tinggi menunjukkan semakin besar kemampuan perusahaan untuk memenuhi kewajiban finansial jangka pendeknya. Meythi (2006) membuktikan bahwa current ratio yang paling baik dalam memprediksi return saham perusahaan manufaktur. Hasil serupa juga di peroleh dari hasil penelitian Wiksuana (2008). Sebaliknya, Wira (2008) menyatakan bahwa current ratio tidak mempunyai pengaruh terhadap return saham.

$\mathrm{H}_{1}$ : Likuiditas berpengaruh terhadap return saham.

Asset size merupakan salah satu cara untuk mengukur firm size (ukuran perusahaan). Ukuran perusahaan (size) menggambarkan besar kecilnya suatu perusahaan yang ditunjukkan oleh total aktiva, jumlah penjualan, rata-rata tingkat penjualan dan rata-rata total aktiva. Dalam penelitian ini ukuran perusahaan diukur dengan menggunakan total aktiva. Perusahaan yang berskala besar akan lebih mudah memperoleh pinjaman dibandingkan dengan perusahaan kecil. Perusahaan yang lebih besar memiliki pertumbuhan yang lebih besar dibandingkan perusahaan kecil, sehingga tingkat pengembalian (return) saham perusahaan besar lebih besar dibandingkan return saham pada perusahaan berskala kecil. Dhatt et al. (1997) membuktikan bahwa ukuran perusahaan tidak berpengaruh terhadap return saham perusahaan manufaktur.

$\mathrm{H}_{2}$ : Ukuran perusahaan berpengaruh terhadap return saham.

DER mencerminkan kemampuan perusahaan dalam memenuhi seluruh kewajibannya. DER menunjukkan hubungan antara jumlah pinjaman jangka panjang yang diberikan oleh para kreditur dengan jumlah modal sendiri yang diberikan oleh pemilik perusahaan. Hal ini biasanya di gunakan untuk mengukur financial leverage dari suatu perusahaan (Syamsyudin, 2007: 54). DER juga memberikan jaminan tentang seberapa besar hutang-hutang perusahaan dijamin modal sendiri. Semakin tinggi ratio menunjukkan bahwa hutang semakin tinggi tetapi tingkat pengembalian yang diharapkan juga lebih tinggi pada saat perusahaan 
mendapatkan keuntungan yang besar sehingga biaya bunga akan meningkat yang akan mengurangi laba perusahaan. Berkurangnya laba perusahaan akan mengurangi minat investor untuk memegang saham perusahaan tersebut, disamping itu risiko hutang perusahaan tidak terbayar juga akan meningkat. DER yang terlalu tinggi mempunyai dampak buruk terhadap kinerja perusahaan, karena tingkat hutang yang semakin tinggi berarti beban bunga perusahaan akan semakin besar dan mengurangi keuntungan.

Dhatt et al. (1997), Anastasia et al. (2003), Wiksuana (2008) membuktikan bahwa DER mempunyai pengaruh yang signifikan terhadap terhadap return saham. Hasil serupa juga di peroleh dari hasil penelitian Susilowati (2011) dan Sparta (2011). Sebaliknya, Subalno (2009) menyatakan bahwa DER tidak terbukti berpengaruh terhadap return saham.

$\mathrm{H}_{3}$ : DER berpengaruh terhadap return saham.

ROE merupakan suatu pengukuran dari penghasilan (income) yang tersedia bagi para pemilik perusahaan atas modal yang mereka investasikan dalam perusahaan (Syamsyudin, 2007: 64). Dengan kata lain, ROE merupakan ukuran kemampuan perusahaan (emiten) dalam menghasilkan keuntungan dengan menggunakan modal sendiri. Rasio ini diperoleh dengan membagi laba setelah pajak dengan rata-rata modal sendiri. Dari sudut pandang investor, ROE merupakan salah satu indikator penting untuk menilai prospek perusahaan di masa mendatang. Indikator ROE sangat penting diperhatikan untuk mengetahui sejauh mana investasi yang akan dilakukan investor di suatu perusahaan mampu memberikan return yang sesuai dengan tingkat yang diharapkan investor. Dalam menentukan pilihannya, investor biasanya akan mempertimbangkan perusahaan yang mampu memberikan kontribusi ROE yang lebih besar. Semakin tinggi ROE menunjukkan kinerja perusahaan semakin baik dan berdampak pada meningkatnya harga saham perusahaan. Jika harga saham semakin meningkat maka return saham juga akan meningkat, maka secara teoritis, sangat dimungkinkan ROE berpengaruh positif terhadap return saham. Anastasia et al. (2003) dan Wiksuana (2008) membuktikan bahwa ROE mempunyai pengaruh terhadap harga saham perusahaan properti. Sebaliknya, Susilowati (2011) menyatakan bahwa ROE tidak berpengaruh terhadap 
return saham perusahaan manufaktur yang terdaftar di BEI tahun 2006 sampai tahun 2008.

$\mathrm{H}_{4}$ : Return on equity berpengaruh terhadap return saham.

EPS menggambarkan jumlah rupiah yang diperoleh untuk setiap lembar saham biasa (Syamsyudin, 2007: 66). EPS merupakan perbandingan antara jumlah earning after tax (EAT) dengan jumlah saham yang beredar. EPS merupakan komponen penting yang harus diperhatikan dalam analisa perusahaan. Informasi EPS suatu perusahaan menunjukkan besarnya laba bersih perusahaan yang siap dibagikan kepada semua pemegang saham (Tandelilin, 2010: 374). Dengan kata lain, EPS menggambarkan prospek earning perusahaan di masa mendatang, maka semakin besar EPS akan menarik investor untuk melakukan investasi diperusahaan tersebut. Oleh karena itu, hal tersebut akan mengakibatkan permintaan akan saham meningkat dan harga saham akan meningkat, dengan demikian EPS berpengaruh positif terhadap return saham. Sparta (2011) membuktikan bahwa EPS mempengaruhi harga saham perusahaan industri manufaktur. Sebaliknya, Dhatt et al. (1997), Haruman (2005) dan Susilowati (2011) menyatakan bahwa EPS tidak berpengaruh terhadap return saham perusahaan manufaktur.

$\mathrm{H}_{5}$ : Earnings Per share berpengaruh terhadap return saham.

PER di ukur dengan nilai deviasi standar dari PER. PER menggambarkan apresiasi pasar terhadap kemampuan perusahaan dalam menghasilkan laba atau menggambarkan rasio atau perbandingan antara harga saham terhadap earning perusahan. Dengan kata lain, PER menunjukkan seberapa besar investor berminat untuk membayar tiap satuan moneter untuk pendapatan yang di terimanya (Tandelilin, 2010: 375). Perusahaan yang diharapkan tumbuh dengan tingkat pertumbuhan yang tinggi (berarti mempunyai prospek yang lebih baik), mempunyai PER yang tinggi juga. Sebaliknya, perusahaan yang di harapkan mempunyai pertumbuhan yang rendah akan mempunyai PER yang rendah juga (Hanafi, 2005: 43). Haruman (2005) membuktikan bahwa PER tidak berpengaruh terhadap tingkat pengembalian saham.

$\mathrm{H}_{6}$ : Price Earnings berpengaruh terhadap return saham.

Risiko Sistematik diukur dengan koefisien beta $(\beta)$. Beta saham mengukur tingkat kepekaan saham terhadap perubahan pasar. Untuk menghitung beta 
digunakan teknik regresi yaitu mengestimasi beta sekuritas dengan menggunakan return-return sekuritas sebagai variabel terikat dan return-return pasar sebagai variabel bebas. Semakin besar beta suatu sekuritas semakin besar kepekaan return sekuritas tersebut terhadap perubahan return pasar (Tandelilin, 2010: 68). Meningkatnya risiko sistematik suatu saham akan mengurangi minat investor. Risiko sistematik suatu saham ditunjukkan dengan beta $(\beta)$. Dengan demikian, semakin besar beta maka semakin besar pula tingkat keuntungan yang diharapkan, semakin berisiko suatu investasi (yang ditunjukkan oleh koefisien betanya), semakin rendah pula harga sahamnya. Anastasia et al. (2003) menyatakan bahwa risiko sistematik (beta) mempunyai pengaruh yang signifikan terhadap harga saham perusahaan properti. Dhatt et al. (1997) membuktikan bahwa stock return berkaitan positif dengan beta.

$\mathrm{H}_{7}$ : Risiko sistematik berpengaruh terhadap return saham.

\section{METODE PENELITIAN}

\section{Pendekatan Penelitian}

Penelitian ini tergolong dalam penelitian positif kuantitatif. Penelitian positif meneliti tentang sebab dan akibat terjadinya suatu realitas sosial secara objektif. Tujuan dari penelitian ini adalah untuk menjelaskan dan memprediksi suatu fenomena dalam masyarakat agar dapat tercapai suatu kesimpulan yang sifatnya umum (general). Dalam penelitian positif kuantitatif, penjelasan tersebut dilakukan dengan menggunakan persamaan matematis.

\section{Tempat Dan Waktu Penelitian}

Penelitian di lakukan di pojok Bursa Efek Indonesia Fakultas Ekonomi Universitas Brawijaya Malang. Ditetapkannya Bursa Efek Indonesia sebagai tempat penelitian, dengan pertimbangan bahwa Bursa Efek Indonesia merupakan pusat informasi perusahaan yang go publik di Indonesia, dimana laporan keuangannya menggunakan standar akuntansi yang sama dan cenderung lebih valid karena telah di audit oleh pihak independen. Di samping itu pengambilan data dilakukan di pojok BEI Universitas Brawijaya adalah untuk memudahkan akses bagi peneliti karena tempat yang mudah dijangkau. 
Penelitian melakukan pengamatan terhadap faktor fundamental dan risiko sistematis perusahaan manufaktur yang terdaftar di Bursa Efek Indonesia tahun 2008-2011 yang diduga berpengaruh terhadap return saham. Data yang dibutuhkan diunduh pada tahun 2012, yaitu pada saat penelitian ini dilakukan.

\section{Metode Pengambilan Sampel}

Populasi adalah keseluruhan unsur-unsur atau data yang akan diteliti atau yang dijadikan sebagai obyek penelitian. Dalam penelitian ini, populasi yang digunakan adalah seluruh perusahaan manufaktur yang terdaftar di Bursa Efek Indonesia pada tahun 2008-2011. Metode pengambilan sampel yang digunakan dalam penelitian ini adalah non probability sampling dalam hal ini purposive sampling dengan mengambil sampel yang telah ditentukan sebelumnya berdasarkan maksud dan tujuan penelitian. Sampel dipilih dengan kriteria sebagai berikut :

Perusahaan yang dipilih adalah perusahaan jenis manufaktur yang telah terdaftar di Bursa Efek Indonesia selama periode tahun 2008 sampai tahun 2011 yang sahamnya aktif diperdagangkan di BEI. Perusahaan manufaktur yang telah menerbitkan laporan keuangan yang lengkap yang telah di audit pada Bursa Efek Indonesia selama periode tahun 2008 sampai periode tahun 2011. Perusahaan manufaktur yang mempunyai laba positif selama periode tahun 2008 sampai tahun 2011.

\section{Metode Pengumpulan Data}

Data yang digunakan dalam penelitian ini adalah data sekunder. Data sekunder adalah data yang dikumpulkan dari luar obyek dan merupakan data yang sudah jadi dan dipublikasikan untuk konsumsi umum oleh instansi atau lembaga yang mengumpulkan, mengolah dan menyajikan, antara lain : Daftar perusahaan yang terdaftar di Bursa Efek Indonesia dan daftar perusahaan yang termasuk dalam sektor manufaktur didapatkan dari situs resmi Bursa Efek Indonesia.

Prosedur pengumpulan data dimulai dengan mendokumentasikan daftar perusahaan yang terdaftar di Bursa Efek Indonesia dan daftar perusahaan yang termasuk dalam sektor manufaktur kemudian data-data yang ada tersebut dipilih berdasarkan karakteristik populasi yang telah ditetapkan sebelumnya. Transaksi yang mengandung informasi tidak lengkap atau di luar ketentuan di atas dihapuskan. Selanjutnya, daftar nama perusahaan manufaktur dan faktor-faktor 
fundamental perusahaan manufaktur didokumentasikan ke dalam program Microsoft Excel.

\section{Metode analisis data.}

Metode analisis yang digunakan dalam penelitian ini adalah regresi linear berganda (multiple regression analysis) untuk menguji hipotesis yang dibangun. Analisis ini digunakan untuk menguji apakah hipotesis penelitian terbukti signifikan atau tidak. Analisis ini untuk menguji kemampuan variabel Likuiditas, Ukuran Perusahaan, Debt to Equity Ratio, Return On Equity, Earnings per Share, Price Earnings Ratio dan Risiko Sistematis terhadap return saham pada saham manufaktur dari tahun 2008 sampai tahun 2011. Secara sistematik persamaan tersebut dapat disederhanakan dalam model matematis sebagai berikut :

$$
\begin{aligned}
& \mathrm{Y}=\alpha+\beta_{1} \mathrm{x}_{1}+\beta_{2} \mathrm{x}_{2}+\beta_{3} \mathrm{x}_{3}+\beta_{4} \mathrm{x}_{4}+\beta_{5} \mathrm{x}_{5}+\beta_{6} \mathrm{x}_{6}+\beta_{7} \mathrm{x}_{7}+\varepsilon_{\mathrm{i}} \\
& \text { Dimana : } \\
& \mathrm{Y}=\text { Return saham sebagai variabel dependen. } \\
& \alpha=\text { Konstanta } \\
& \beta=\text { Koefisien regresi } \\
& \mathrm{X}_{1} \quad=\text { Likuiditas } \\
& \mathrm{X}_{2}=\text { Ukuran perusahaan } \\
& \mathrm{X}_{3}=\text { Debt to Equity Ratio } \\
& \mathrm{X}_{4} \quad=\text { Return On Equity } \\
& \mathrm{X}_{5} \quad=\text { Earnings Per Share } \\
& \mathrm{X}_{6}=\text { Price Earnings Ratio } \\
& \mathrm{X}_{7} \quad=\text { Risiko Sistematis } \\
& \varepsilon_{\mathrm{i}} \quad=\text { Faktor penganggu } / \text { nilai residual }
\end{aligned}
$$

\section{HASIL DAN PEMBAHASAN}

\section{Analisis Deskriptif Variabel}

Penelitian ini bertujuan untuk menganalisis pengaruh faktor fundamental perusahaan yang terdiri atas likuiditas, ukuran perusahaan, debt to equity ratio, return on equity, earnings per share, price earnings ratio dan risiko sistematis pada saham perusahaan manufaktur dari tahun 2008 sampai tahun 2011. Dari 164 perusahaan manufaktur yang terdaftar di BEI hanya 54 perusahaan yang memenuhi 
semua syarat penelitian untuk dijadikan sampel tersebut dan atas beberapa sampel digugurkan karena tidak memenuhi kriteria yang telah ditetapkan dan tidak didukung kelengkapan data.

Hasil penelitian di jelaskan berdasarkan analisa data. Analisa data yang digunakan adalah analisa deskriptif variabel dan analisis uji hipotesis dengan menggunakan model regresi linear berganda secara pooled yang diolah dengan menggunakan software SPSS 18, maka diperoleh data pengamatan sebanyak 4 x 54 $=216$ data.

Analisis deskriptif variabel ini memberikan gambaran mengenai data yang terdiri atas likuiditas, ukuran perusahaan, debt to equity ratio, return on equity, earnings per share, price earnings ratio dan risiko sistematis, nilai minimum dan maksimum, berapa besarnya rata-rata dan deviasi standar dari data-data perusahaan manufaktur tersebut setiap tahun mulai tahun 2008-2011. Hasil uji statistik deskriptif data dapat dilihat pada tabel 1.2 sebagai berikut:

Pada Tabel 1.2 di atas menunjukkan bahwa jumlah pengamatan dalam penelitian ini sebanyak 216 (hasil perkalian periode penelitian sebanyak 4 periode pengamatan dengan jumlah sampel sebanyak 54 perusahaan). Return saham

Hasil Uji Statistik Deskriptif

Tabel 1.2

\begin{tabular}{|l|l|l|l|l|}
\hline \multicolumn{1}{|c|}{ Variabel } & Mean & $\begin{array}{r}\text { Std. } \\
\text { Deviation }\end{array}$ & m & Minimu \\
\hline Likuiditas & 24.346 & 185.129 & 0.35 & 10.68 \\
Ukuran & 101.064 & 224.407 & 4.9 & 13.18 \\
Perusahaan & & & & \\
DER & 10.013 & 0.99191 & 0.08 & 8.44 \\
ROE & 0.2684 & 0.70631 & 0 & 9.5 \\
EPS & 4.84 & 2.171 & -4 & 10 \\
PER & 172.169 & 2.832 .021 & 0.15 & 252.45 \\
Risiko & 0.7479 & 104.708 & -8.09 & 4.85 \\
Sistematis & & & & \\
Y & 0.3495 & 0.66458 & -1.74 & 3.45 \\
\hline
\end{tabular}

terendah adalah $-1,74$ atau $-174 \%$ dan return saham tertinggi 3,45 atau $345 \%$. Nilai return saham bertanda negatif ini menunjukkan bahwa secara umum harga saham perusahaan sampel mengalami penurunan. Dari data di atas dapat diketahui bahwa return saham secara rata-rata mengalami perubahan sebesar 0,3495 atau $34,95 \%$. Deviasi standar return saham sebesar 0,66458 atau $66,45 \%$ yang melebihi nilai 
rata-rata saham menunjukkan tingginya fluktuasi data variabel return saham selama periode pengamatan.

Nilai suatu perusahaan bisa dilihat dari return saham perusahaan yang bersangkutan di pasar modal. Return saham biasanya berfluktuasi mengikuti kekuatan permintaan dan penawaran. Fluktuasi return saham mencerminkan seberapa besar minat investor terhadap saham suatu perusahaan. Return saham setiap saat bisa mengalami perubahan seiring dengan minat investor untuk menempatkan modalnya pada suatu saham.

Nilai rata-rata likuiditas sebesar 24,346 selama tahun 2008 sampai dengan 2011, dengan nilai maximum sebesar 10,68 dan minimum sebesar 0,35. Deviasi standar likuiditas sebesar 185,129 lebih besar jika dibandingkan nilai rata-rata sebesar 24,346. Dengan besarnya simpangan data, menunjukkan tingginyanya fluktuasi data variabel likuiditas.

Nilai rata-rata ukuran perusahaan sebesar 101,064 selama tahun 2008 sampai dengan 2011, dengan nilai maximum sebesar 13,18 dan minimum sebesar 4,90. Deviasi standar ukuran perusahaan sebesar 224,407 lebih besar jika dibandingkan nilai rata-rata sebesar 101,064. Jika dibandingkan dengan nilai rata-rata ukuran perusahaan maka dapat disimpulkan bahwa deviasi standar ukuran perusahaan lebih besar dibanding dengan rata-ratanya. Hal ini menunjukkan tingginyanya fluktuasi data variabel ukuran perusahaan. Rata-rata ukuran perusahaan mencerminkan kondisi ukuran perusahaan sesungguhnya dari perusahaan manufaktur yang tercatat di BEI dari tahun 2008 sampai tahun 2011.

Nilai rata-rata DER sebesar 10,013 menunjukkan kemampuan modal sendiri perusahaan untuk dijadikan jaminan semua hutang perusahaan yang positif selama tahun 2008 sampai tahun 2011 dengan nilai maximum sebesar 8,44 dan minimum sebesar 0,08. Deviasi standar DER sebesar 0,99191 lebih kecil dibandingkan nilai rata-rata sebesar 10,013. Dengan kecilnya simpangan data, menunjukkan rendahnya fluktuasi data variabel DER. Dengan melihat nilai rata-rata variabel DER tersebut maka hal ini menunjukkan rata-rata hutang perusahaan adalah sebesar 8,44 kali dibanding dengan modal sendiri yang dimiliki perusahaan. Hal ini menunjukkan bahwa banyak perusahaan yang lebih banyak menggunakan hutang kepada pihak 
ketiga dibanding dengan memanfaatkan modal sendiri mereka untuk pendanaan perusahaan.

Nilai rata-rata ROE sebesar 0,2684 menunjukkan kemampuan modal sendiri perusahaan untuk dijadikan jaminan semua hutang perusahaan yang positif selama tahun 2008 sampai tahun 2011 dengan nilai maximum sebesar 9,50 dan minimum sebesar 0,00. Deviasi standar ROE sebesar 0,70631 lebih besar dibandingkan nilai rata-rata sebesar 0,2684. Dengan besarnya simpangan data, menunjukkan tingginya fluktuasi data variabel ROE. Hal ini menunjukkan bahwa secara rata-rata di dapat laba perusahaan sebesar 0,2684 kali dibanding dengan modal sendiri yang dimiliki perusahaan sebagai sumber pendanaannya.

Nilai rata-rata EPS sebesar 4,84 dengan nilai maximum sebesar 10 dan minimum sebesar -4. Deviasi standar EPS sebesar 2,171 lebih kecil dibandingkan nilai rata-rata sebesar 4,84. Jika dibandingkan dengan nilai rata-rata EPS maka dapat disimpulkan bahwa deviasi standar EPS tidak terlalu besar dibanding dengan rata-ratanya. Hal ini menunjukkan bahwa variasi EPS dari seluruh sampel perusahaan tidaklah terlalu besar.

Nilai rata-rata PER sebesar 172,169 dengan nilai maximum sebesar 252,45 dan minimum sebesar 0,15. Deviasi standar PER sebesar 2.832,021 lebih besar dibandingkan nilai rata-rata sebesar 172,169. Dengan adanya nilai deviasi standar yang cukup besar dibandingkan dengan nilai rata-ratanya, menunjukkan bahwa variasi PER dari perusahaan yang dijadikan sampel cukup besar. Nilai rata-rata PER sebesar 172,169 yang memiliki arti bahwa secara umum perusahaanperusahaan yang menjadi sampel penelitian memiliki harga saham 172,169 kali dari earning per share.

Nilai rata-rata risiko sistematik diukur dengan koefisien beta $(\beta)$ yaitu sebesar 0,7479 dengan nilai maximum sebesar 4,85 dan beta minimum sebesar $-8,09$. Beta maksimum adalah beta lebih dari satu $(\beta>1)$, hal ini terjadi pada saham yang cenderung bergerak searah dengan pasar dan sangat besar pergerakannya. Saham dengan beta lebih dari satu lebih tidak stabil atau lebih mudah berubah dibandingkan rata-rata saham, saham ini disebut sebagai saham agresif.

Deviasi standar beta sebesar 104,708 lebih besar dibandingkan nilai mean sebesar 0,7479. Hal ini menunjukkan bahwa pada saat itu saham perusahaan 
manufaktur cenderung bergerak searah dengan pasar tetapi tidak terlalu besar pergerakannya. Saham dengan beta kurang dari satu lebih stabil atau lebih sedikit berubah daripada rata-rata saham, saham ini disebut sebagai saham defensif. Dengan nilai deviasi standar yang hampir sama dengan nilai rata-ratanya, hal ini menunjukkan bahwa variabel beta dari perusahaan yang dijadikan sampel tidaklah memiliki variasi yang besar.

\section{Hasil Uji Signifikansi Variabel (Uji t)}

Dari data yang diperoleh kemudian dianalisis dengan metode regresi dan dihitung dengan menggunakan program SPSS. Berdasar output SPSS tersebut secara parsial pengaruh dari ketujuh variabel independen yaitu likuiditas, ukuran perusahaan, debt to equity ratio, return on equity, earnings per share, price earnings ratio dan risiko sistematis terhadap return saham ditunjukkan pada Tabel 1.3 sebagai berikut:

Tabel 1.3

Hasil Uji Regresi Linier Berganda

Coefficientsa

\begin{tabular}{|l|l|l|l|l|}
\hline Variabel & $\begin{array}{l}\text { Koefesien } \\
\text { Regresi }\end{array}$ & $\begin{array}{l}\text { Std. } \\
\text { Error }\end{array}$ & $\mathrm{t}$ & Sig $(\mathrm{p})$ \\
\hline Likuiditas & -0.065 & 0.028 & -0.834 & 0.405 \\
Ukuran & 0.107 & 0.022 & 1.445 & 0.15 \\
Perusahaan & & & & \\
DER & -0.058 & 0.05 & -0.78 & 0.436 \\
ROE & -0.005 & 0.064 & -0.07 & 0.944 \\
EPS & 0.239 & 0.025 & 2.922 & $.004^{*}$ \\
PER & 0.053 & 0.002 & 0.727 & 0.468 \\
Risiko Sistematis & 0.281 & 0.043 & 4.119 & $.000^{*}$ \\
\hline
\end{tabular}

Dengan melihat Tabel 1,3 dengan statistik signifikansi $(\alpha)=0,05$ maka persamaan regresi di atas bila dikaitkan dengan uji hipotesa yang penulis ajukan mempunyai makna sebagai berikut :

Likuiditas berpengaruh negatif dan tidak signifikan terhadap return saham. Dari hasil penelitian diperoleh nilai koefisien regresi untuk likuiditas sebesar -0,065 dan nilai t sebesar -0,834 dengan signifikansi (p) sebesar 0,405 lebih besar dari signifikansi $\alpha=0,05$. Dengan demikian hipotesis pertama yang menyatakan likuiditas memiliki pengaruh yang signifikan terhadap return saham ditolak. 
Ukuran Perusahaan berpengaruh positif dan tidak signifikan terhadap return saham. Dari hasil penelitian diperoleh nilai koefisien regresi untuk ukuran perusahaan sebesar 0,107 dan nilai t sebesar 1,445 dengan signifikansi (p) sebesar 0,15 lebih besar dari signifikansi $\alpha=0,05$. Dengan demikian hipotesis kedua yang menyatakan ukuran perusahaan memiliki pengaruh yang signifikan terhadap return saham ditolak.

DER berpengaruh negatif dan tidak signifikan terhadap return saham. Dari hasil penelitian diperoleh nilai koefisien regresi untuk DER sebesar -0,058 dan nilai t sebesar -0,78 dengan signifikansi (p) sebesar 0,436 lebih besar dari signifikansi $\alpha$ $=0,05$. Dengan demikian hipotesis ketiga yang menyatakan DER memiliki pengaruh signifikan terhadap return saham ditolak.

ROE berpengaruh negatif dan tidak signifikan terhadap return saham. Dari hasil penelitian diperoleh nilai koefisien regresi untuk ROE sebesar -0,005 dan nilai t sebesar -0,07 dengan signifikansi (p) sebesar 0,944 lebih besar dari signifikansi $\alpha$ $=0,05$. Dengan demikian hipotesis keempat yang menyatakan ROE memiliki pengaruh yang signifikan terhadap return saham ditolak.

EPS berpengaruh positif dan signifikan terhadap return saham. Dari hasil penelitian diperoleh nilai koefisien regresi untuk EPS sebesar -0,239 dan nilai t sebesar 2,922 dengan signifikansi (p) sebesar 0,004 lebih kecil dari signifikansi $\alpha=$ 0,05. Dengan demikian hipotesis kelima yang menyatakan EPS memiliki pengaruh yang signifikan terhadap return saham diterima.

PER berpengaruh positif dan tidak signifikan terhadap return saham. Dari hasil penelitian diperoleh nilai koefisien regresi untuk PER sebesar 0,053 dan nilai t sebesar 0,727 dengan signifikansi (p) sebesar 0,468 lebih besar dari signifikansi $\alpha=$ 0,05. Dengan demikian hipotesis keenam yang menyatakan PER memiliki pengaruh signifikan terhadap return saham ditolak.

Risiko sistematis berpengaruh positif dan signifikan terhadap return saham. Dari hasil penelitian diperoleh nilai koefisien regresi untuk risiko sistematis sebesar 0,281 dan nilai t sebesar 4,119 dengan signifikansi (p) sebesar 0,000 lebih besar dari signifikansi $\alpha=0,05$. Dengan demikian hipotesis ketujuh yang menyatakan risiko sistematis berpengaruh signifikan terhadap return saham diterima. 
Pengujian hipotesis dilakukan untuk mengetahui pengaruh dari ketujuh variabel fundamental secara parsial terhadap return saham. Hasilnya menunjukan bahwa variabel fundamental yang berpengaruh terhadap return saham adalah EPS dan risiko sistematis. Hal ini di tunjukkan dari nilai t-hitung ataupun tingkat probabilitasnya yang kurang dari 0,05. Variabel fundamental yang berpengaruh tidak signifikan terhadap return saham adalah likuiditas, ukuran perusahaan, DER, ROE dan PER. Hal ini di tunjukkan dari nilai t-hitung ataupun tingkat probabilitasnya yang lebih besar dari 0,05 .

\section{PEMBAHASAN PENELITIAN}

Hasil uji hipotesis menunjukkan bahwa secara simultan variabel independen yang terdiri atas likuiditas, ukuran perusahaan, debt to equity ratio, return on equity, earnings per share, price earnings ratio dan risiko sistematis mempunyai pengaruh yang signifikan terhadap return saham. Hasil penelitian ini sesuai dengan penelitian terdahulu yang dilakukan oleh Haruman (2005). Adanya pengaruh ini membuktikan bahwa informasi berdasarkan fundamental perusahaan berguna bagi pengambilan keputusan investasi saham. Laporan keuangan mampu mempengaruhi harga sekuritas karena pergerakan harga saham merupakan refleksi dari kinerja manajemen sehingga informasi laporan keuangan dalam bentuk variabel akuntansi (variabel fundamental) dapat digunakan untuk menilai return saham.

Kontribusi variabel independen yang merupakan variabel fundamental terhadap return saham adalah kecil di bawah 50\%, hal ini disebabkan karena harga saham terbentuk oleh mekanisme supplay dan demand atas saham tersebut. Supply dan demand tersebut terjadi karena adanya banyak faktor, baik faktor yang sifatnya spesifik atas saham tersebut seperti kinerja perusahaan dan industri dimana perusahaan tersebut bergerak maupun faktor yang sifatnya makro seperti kondisi ekonomi negara, kondisi sosial dan politik. Dengan kata lain, investor tidak hanya mengambil keputusan investasi berdasarkan kondisi mikro tapi juga kondisi makro perusahaan tersebut. Keputusan investasi ini juga dipengaruhi oleh karakter individu investor, apakah long term investment atau short term investment, dimana investor yang menginginkan keuntungan jangka pendek bersifat cenderung spekulatif karena keputusan investasinya sangat dipengaruhi oleh kondisi makro. 
Hasil pengujian hipotesis secara parsial menunjukkan bahwa variabel fundamental yang berpengaruh signifikan terhadap return saham adalah EPS dan risiko sistematis, dimana variabel yang paling berpengaruh terhadap return saham adalah risiko sistematis dan variabel yang tidak berpengaruh signifikan terhadap return saham adalah likuiditas, ukuran perusahaan, DER, ROE dan PER. Hasil penelitian ini sesuai dengan hasil penelitian Haruman (2005), meskipun terdapat beberapa hasil penelitian yang tidak sama yaitu EPS secara parsial memiliki pengaruh yang tidak signifikan dalam penelitian Haruman (2005) tetapi signifikan dalam penelitian ini.

\section{Pengaruh Liquidity terhadap Return Saham}

Berdasarkan hasil analisis regresi variabel likuiditas secara parsial tidak mempunyai pengaruh signifikan terhadap return saham. Hasil penelitian ini menunjukkan bahwa informasi perubahan likuiditas yang diperoleh dari laporan keuangan tidak berpengaruh pada keputusan atas harga saham pada industri manufaktur di pasar modal Indonesia. Hal ini mungkin terjadi karena investor dalam melakukan investasi tidak memandang penting ratio aktiva lancar dengan hutang lancar yang dimiliki perusahaan. Rasio likuiditas perusahaan tidak mempengaruhi persepsi investor terhadap keuntungan di masa yang akan datang.

Nilai koefisien likuiditas yang negatif mengindikasikan nilai aktiva lancar lebih kecil daripada nilai hutang lancar. Dengan penurunan likuiditas perusahaan maka akan menurunkan return saham. Jika return saham tersebut menurun maka saham tersebut tidak diminati para investor, begitupun sebaliknya. Semakin tinggi likuiditas menunjukkan kinerja perusahaan semakin baik berarti semakin kecil risiko kegagalan perusahaan dalam memenuhi kewajiban jangka pendeknya. Akibatnya resiko yang ditanggung perusahaan juga semakin kecil. Dengan semakin kecilnya resiko yang ditanggung perusahaan maka diharapkan akan meningkatkan minat para investor untuk menananamkan dananya dalam perusahaan tersebut, sehingga investor lebih menyukai likuiditas yang tinggi dibandingkan likuiditas yang rendah. Dapat disimpulkan bahwa makin tinggi likuiditas suatu perusahaan maka akan semakin tinggi return saham. Penelitian ini konsisten dengan penelitian yang dilakukan Wira (2008) yang menunjukkan bahwa likuiditas tidak mempunyai pengaruh secara parsial terhadap return saham. 


\section{Pengaruh Ukuran Perusahaan terhadap Return Saham}

Ukuran perusahaan (size) menggambarkan besar kecilnya suatu perusahaan yang ditunjukkan oleh total aktiva, jumlah penjualan, rata-rata tingkat penjualan dan rata-rata total aktiva. Perusahaan yang berskala besar akan lebih mudah memperoleh pinjaman dibandingkan dengan perusahaan kecil. Dalam penelitian ini ukuran perusahaan diukur dengan menggunakan total aktiva. Perusahaan yang lebih besar memiliki pertumbuhan yang lebih besar dibandingkan perusahaan kecil. Berdasarkan hasil analisis variabel ukuran perusahaan secara parsial tidak mempunyai pengaruh signifikan terhadap return saham. Hasil penelitian ini menunjukkan bahwa besar kecilnya ukuran perusahaan tidak dapat digunakan untuk memprediksi tingkat keuntungan saham (return). Penelitian ini tidak konsisten dengan penelitian yang dilakukan Dhatt et al. (1999) yang menunjukkan bahwa assets size mempunyai pengaruh secara parsial terhadap return saham.

\section{Pengaruh DER terhadap Return Saham}

Berdasarkan hasil analisis regresi variabel DER secara parsial tidak mempunyai pengaruh signifikan terhadap return saham. Hasil penelitian ini menunjukkan bahwa semakin tinggi rasio hutang perusahaan dapat digunakan untuk memprediksi menurunnya tingkat keuntungan saham (return). Sebaliknya, semakin rendah rasio hutang perusahaan dapat digunakan untuk memprediksi meningkatnya tingkat keuntungan saham (return). Hal ini disebabkan karena adanya pertimbangan yang berbeda dari beberapa investor dalam memandang DER.

Bagi sebagian investor, DER dipandang sebagai besarnya tanggung jawab perusahaan terhadap pihak ketiga yaitu kreditor yang memberikan pinjaman kepada perusahaan, sehingga semakin besar nilai DER akan memperbesar tanggungan perusahaan. Namun demikian nampaknya beberapa investor memandang bahwa perusahaan yang tumbuh pasti akan memerlukan hutang sebagai dana tambahan untuk memenuhi pendanaan pada perusahaan yang tumbuh.

Dalam hal ini perusahaan yang tumbuh akan memerlukan banyak dana operasional yang tidak mungkin dapat dipenuhi hanya dari modal sendiri yang dimiliki perusahaan. Perbedaan pandangan tersebut menyebabkan kurang signifikannya pengaruh DER terhadap return saham. Penelitian ini didukung oleh penelitian sebelumnya yang dilakukan oleh Anastasia (2003) dan tidak konsisten 
dengan penelitian yang dilakukan Dhatt et al. (1999) dan Susilowati (2011) yang menunjukkan bahwa DER mempunyai pengaruh secara parsial terhadap return saham.

\section{Pengaruh ROE terhadap Return Saham}

Berdasarkan hasil analisis variabel ROE secara parsial tidak mempunyai pengaruh signifikan terhadap return saham. Pendapatan bersih perusahaan dan Modal saham yang dimiliki perusahaan mengakibatkan naik atau turunnya harga saham. Hasil ini bertentangan dengan teori bahwa ROE merupakan tolak ukur profitabilitas, dimana para pemegang saham pada umumnya ingin mengetahui tingkat probabilitas modal saham dan keuntungan yang telah mereka tanam kembali dalam bentuk laba yang ditanam. Apabila saham perusahaan diperdagangkan di bursa saham, tinggi rendahnya ROE akan mempengaruhi tingkat permintaan saham tersebut di bursa dan harga jualnya. Penelitian ini konsisten dengan penelitian yang dilakukan Anastasia (2003) dan Susilowati (2011) yang menunjukkan bahwa ROE tidak mempunyai pengaruh secara parsial terhadap return saham.

\section{Pengaruh EPS terhadap Return Saham}

Berdasarkan hasil analisis regresi variabel EPS secara parsial mempunyai pengaruh signifikan dan berhubungan positif terhadap return saham. Koefisien regresi variabel EPS bertanda positif yang menunjukkan adanya hubungan positif dari EPS yang menyebabkan kenaikan terhadap return saham. Hal ini di karenakan EPS menggambarkan jumlah rupiah yang di peroleh untuk setiap lembar saham biasa. Hal ini disebabkan karena pendapatan per lembar saham akan menentukan keputusan investor dalam investasi dananya. Di samping itu EPS menunjukkan nilai perusahaan.

Hasil ini sejalan dengan teori yang mendasarinya bahwa EPS yang semakin besar akan menunjukkan bahwa kemampuan perusahaan dalam menghasilkan laba bersih setelah pajak semakin meningkat, dengan meningkatnya laba bersih setelah pajak yang dihasilkan oleh perusahaan maka total return yang diterima oleh para pemegang saham juga semakin meningkat. Penelitian ini tidak konsisten dengan penelitian yang dilakukan Haruman (2005), Wira (2008) dan Susilowati (2011) yang menunjukkan bahwa EPS tidak mempunyai pengaruh secara parsial terhadap return saham. 


\section{Pengaruh PER terhadap Return Saham}

Berdasarkan hasil analisis regresi variabel PER secara parsial tidak mempunyai pengaruh signifikan terhadap return saham. Koefisien regresi variabel PER bertanda positif yang menunjukkan adanya hubungan dari PER yang menyebabkan kenaikan terhadap return saham. Hal ini dikarenakan PER merupakan indikator perkembangan atau pertumbuhan di masa yang akan datang. PER memiliki hubungan positif dengan harga saham khususnya return perusahaan. PER juga merupakan salah satu tolak ukur keberhasilan suatu perusahaan sehingga semakin tinggi PER maka semakin tinggi pula harga saham begitu juga return perusahaan. Penelitian ini mendukung penelitian sebelumnya yang dilakukan Dhatt et al. (1999) dan tidak konsisten dengan penelitian yang dilakukan oleh Haruman (2005) yang menunjukkan bahwa PER mempunyai pengaruh secara parsial terhadap return saham.

\section{Pengaruh Risiko Sistematis terhadap Return Saham}

Berdasarkan hasil analisis regresi variabel risiko sistematis secara parsial mempunyai pengaruh signifikan dan berhubungan positif terhadap return saham. Koefisien regresi risiko sistematis bertanda positif yang menunjukkan adanya hubungan positif dari beta saham terhadap return saham. Hal ini karena beta saham berbanding lurus dengan return saham individu sehingga apabila beta saham yang merupakan alat ukur risiko sistematis naik maka return saham juga akan naik. Penelitian ini mendukung penelitian sebelumnya yang dilakukan oleh Haruman (2005) yang menunjukkan bahwa risiko sistematis mempunyai pengaruh secara parsial terhadap return saham dan tidak konsisten dengan penelitian yang dilakukan Anastasia (2003).

\section{SIMPULAN}

Secara parsial, bahwa variabel fundamental yang berpengaruh signifikan terhadap return saham adalah earning per share dan risiko sistematis. Sedangkan likuiditas, ukuran perusahaan, DER, ROE dan PER tidak terbukti berpengaruh terhadap return saham.

Secara simultan, variabel independen yang terdiri atas likuiditas, ukuran perusahaan, debt to equity ratio, return on equity, earnings per share, price 
earnings ratio dan risiko sistematis mempunyai pengaruh yang signifikan terhadap return saham.

\section{DAFTAR PUSTAKA}

Anastasia, N., Gunawan, Y. W., dan Wijiyanti, I. 2003. Analisis Faktor Fundamental dan Risiko Sistematik Terhadap Harga Saham Properti di BEJ, Jurnal Akuntansi \& Keuangan, Universitas Kristen Petra 5 (2): 123-132.

Ang, R. 1997, Buku Pintar: Pasar Modal Indonesia, Mediasoft Indonesia, Jakarta.

Breadley, R. A., Myers, S. C., dan Marcus, A. J. 2008. Dasar-dasar Manajemen Keuangan Perusahaan, Edisi Kelima. Penerbit Erlangga. Jakarta.

Dhatt, S., Kim, Y. H., dan Mukherji, S. 1999. Hubungan antara Stock Return dengan Berbagai Variabel Fundamental di Pasar Modal Korea Selatan, AsiaPacific Financial Markets Journal 6: 221-233.

Elleuch, J. 2009. Fundamental Analysis Strategy and the Prediction of Stock Returns, International Research Journal of Finance and Economics (30): 95107.

Halim, A. 2005. Analisis Investasi. Salemba Empat. Jakarta.

Hardiningsih, P., Suryatno, L., dan Chariri, A. 2001. Pengaruh Faktor Fundamental dan Risiko Ekonomi terhadap Return Saham pada Perusahaan di Bursa Efek Jakarta, Jurnal Strategi Bisnis 8: 83-97.

Hartono, J. 2003. Teori Portofolio dan Analisis Investasi, Edisi Ketiga. BPFE. Yogyakarta.

Haruman, T. 2005. Pengaruh Faktor Fundamental, Indikator Ekonomi Makro dan Risiko Sistematis terhadap Tingkat Pengembalian Saham di BEI, Jurnal Ekonomi dan Manajemen 6 (3): 462-477.

Husnan, S. 2005. Dasar-Dasar Teori Portfolio dan Analisis Sekuritas, Edisi Ketiga. Unit Penerbit dan Percetakan UNP YKPN. Yogyakarta.

Indra, Z. A. 2006. Faktor-Faktor Fundamental Keuangan Yang Mempengaruhi Risiko Saham. Jurnal bisnis dan manajemen 2 (3): 239-256.

Lev, B., dan Thiagarajan, S. R. 1993. Fundamental Information Analysis, Journal of Accounting Research 31 (2): 190-215.

Meythi. 2007. Rasio Keuangan Yang Paling Baik Untuk Memprediksi Return Saham, Jurnal Bisnis Dan Akuntansi 9 (1): 47-65. 
Ou, J., dan Penman, S. 1989. Financial Statement Analysis and the Prediction of Stock Returns, Journal of Accounting and Economics 11: 295-329.

Santoso, S. 2002. Latihan SPSS Statistik Parametrik. Elex Media Komputindo. Jakarta.

Sartono, A. 2001. Manajemen Keuangan Internasional, Edisi Pertama. BPFE. Yogyakarta.

Sparta. 2011. Analisis Validitas Return Net Operating Asset dan Return on Asset dalam Memprediksi Harga Saham pada Industri Manufaktur yang Terdaftar di BEI, Jurnal Keuangan dan Perbankan 8 (1): 33-50.

Subalno, 2009. Analisis Pengaruh Faktor Fundamental Dan Kondisi Ekonomi terhadap Return Saham. Tesis, Universitas Diponegoro Semarang.

Sunardi, H. 2010. Pengaruh Penilaian Kinerja dengan ROI dan EVA terhadap Return Saham pada Perusahaan yang Tergabung dalam Indeks LQ 45 di Bursa Efek Indonesia, Jurnal Akuntansi 2 (1): 70-92.

Susilowati, Y. 2011. Reaksi Signal Rasio Profitabilitas dan Rasio Solvabilitas terhadap Return Saham, Dinamika Keuangan dan Perbankan 3 (1): 17 -37.

Syamsudin, L. 2007. Manajemen Keuangan Perusahaan, Edisi Baru. PT. Raja Grafindo Persada. Jakarta.

Tandelilin, E. 2010. Portofolio dan Investasi, Edisi Pertama. KANISIUS (Anggota IKAPI). Yogyakarta.

Trisnawati, I. 2009. Pengaruh Economic Value Added, Arus Kas Operasi, Residual Income, Earnings, Operating Leverage dan Market Value Added terhadap Return Saham, Jurnal Bisnis Dan Akuntansi 11 (1): 65-78.

Warsono. 2008. Kontribusi Pasar Modal terhadap Perekonomian Indonesia, Economics Bulletin Usahawan XXXVII (4).

Wiksuana, I Gst. Bgs. 2008. Pengaruh Faktor-faktor Fundamental terhadap Return Saham di Bursa Efek Indonesia, Sarathi 15 (3): 401-411.

Wira, V. 2008. Analisa Karakteristik Perusahaan Terhadap Return dan Beta Perusahaan Makanan dan Minuman di Bursa Efek Jakarta, Jurnal Bisnis dan Manajeman 4 (3): 1-110. 